\title{
Appraisal of Soil Potential to Store Organic Carbon in Different Land Uses under Old Alluvium of Indo- Gangetic Plains
}

\author{
K. Rajan ${ }^{1^{*}}$, Sanjeev Kumar ${ }^{2}$, D. Dinesh ${ }^{3}$, P. Raja ${ }^{1}$, B. P. Bhatt ${ }^{2}$ and Deo Karan ${ }^{4}$ \\ ${ }^{1}$ ICAR - Indian Institute of Soil and Water Conservation, Research Centre, \\ Udhagamandalam, The Nilgiris, Tamil Nadu, India \\ ${ }^{2}$ ICAR - Research Complex for Eastern Region, BV College, Patna, Bihar, India \\ ${ }^{3}$ ICAR - Indian Institute of Soil and water Conservation, Research Centre, Vasad, Anand, \\ Gujarat, India \\ ${ }^{4}$ KVK, ICAR Research Complex for Eastern Region, Buxar, Bihar, India
}

*Corresponding author

\section{Keywords}

Soil organic carbon stock, Old alluvium, Agroecological region, IndoGangetic plains

Article Info

Accepted:

15 January 2019

Available Online:

10 February 2019

\section{A B S T R A C T}

Soil potential to stock organic carbon was appraised in hot sub-humid dry agro ecological region (AER 9) of Indo-Gangetic plains with alluvium derived soils i.e. old alluvium with growing period of 150-180 days. The study region is located in South Bihar and it was surveyed for prevailing land uses. There were six land uses viz., rice-wheat-fallow system systems, maize-potato-fallow system, red gram, sugarcane, mango orchard and agroforestry found prominent in the region. Five representative sites in each land use were selected for sampling in Jehanabad and Gaya district in south Bihar. Soil samples were collected from surface to $60 \mathrm{~cm}$ depth with $15 \mathrm{~cm}$ increments for soil organic carbon and core samples for bulk density estimation with standard procedures. The result explained that the soil organic carbon stock was observed highest in mango orchards with $9.6 \mathrm{~kg} \mathrm{~m}^{-2}$ (Range: $7.7-11.8 \mathrm{~kg} \mathrm{~m}^{-2}$ ) followed by agro-forestry with $7.9 \mathrm{~kg} \mathrm{~m}^{-2}$ (Range: $6.4-9.6 \mathrm{~kg}$ $\mathrm{m}^{-2}$ ), Maize-Potato cropping system with $6.7 \mathrm{~kg} \mathrm{~m}^{-2}$ (Range: $5.5-8.2 \mathrm{~kg} \mathrm{~m}^{-2}$ ) Rice-Wheat cropping system with $6.4 \mathrm{~kg} \mathrm{~m}^{-2}$ (Range:5.6 - $7.6 \mathrm{~kg} \mathrm{~m}^{-2}$ ) and red gram mono-crop with $5.8 \mathrm{~kg} \mathrm{~m}^{-2}$ (Range:4.6 - $6.6 \mathrm{~kg} \mathrm{~m}^{-2}$ ). The lowest organic carbon stock of $4.2 \mathrm{~kg} \mathrm{~m}^{-2}$ (Range: $3.7-5.1 \mathrm{~kg} \mathrm{~m}^{-2}$ ) was recorded in sugarcane growing soils. Considering mango orchard as reference in the region, sugarcane, red gram, rice-wheat-fallow, maize-potatofallow and agroforestry has the potential for 54,38,32,29 and $23 \mathrm{t} \mathrm{ha}^{-1}$ of organic carbon to sequester, respectively.

\section{Introduction}

Organic carbon storage in soil is varying due to climate, relief, vegetation and human interventions. Carbon stock has tremendous impacts on improving soil productivity and reducing green house gases emission. Organic carbon storage in an agro ecological region varies based on its land use patterns. Assessment of carbon storage provides an insite on capacity of soil in an agro-eco region to store carbon and opportunity to increase 
carbon storage. The $\mathrm{C}$ stored in the soil zone appears susceptible to enhanced degradation under the projected conditions of global climate change (Lindroth et al., 1998; Sjögersten and Wookey, 2009; Jungqvist et al., 2014). Organic carbon plays a significant role in maintaining physical, chemical and biological quality of soil. Hence the Soil Organic Carbon (SOC) is one of the most important indicators of soil quality (Wang et al., 2003). Higher level of SOC in soil sustains higher productivity in any ecosystem. Various ecosystems such as forest grassland, plantation and agriculture are varying in its soil carbon status mainly due to its vegetations and land uses (Awasthi et al., 2005). Land use and land cover management creates variation in soil organic carbon stocks (Ollinger et al., 2002). An undisturbed forest ecosystem stores highest organic carbon stock due to continuous accumulation of litters compared to other land uses under similar soil and climatic conditions. A major driver of soil $\mathrm{C}$ changes in recent centuries has been Land Use and Land Cover (LULC). Replacement of natural vegetation with croplands usually leads to soil $\mathrm{C}$ loss, while the reverse leads to gain of SOC (Guo and Gifford, 2002). The response of soil $\mathrm{C}$ to LULC depends on the local soil conditions, such as soil type, mineralogy, and texture (Lugo et al., 1986), and on climate influences, such as temperature and soil moisture or precipitation (Marín-Spiotta and Sharma, 2013). Crop cultivation is highly a disturbed ecosystem and the organic carbon stock depends on its level of intensive cultivations. Frequent cultivation with intensive tillage support fast decomposition of stored and applied organic sources and stocks tend to be less compared to forest land (Krishnan et al., 2007). Land degradation processes, especially soil erosion, are severely affecting soil organic carbon compared to other soil properties (Rajan et al., 2010). Poeplau and Don (2013) showed that planting cover crops during winter and tilling them into the soil as additional carbon input which can significantly enhance soil $\mathrm{C}$ on croplands.

Time bound assessment of soil organic carbon stock in different land use systems in any agro eco region is an essential part to correct a faulty agriculture system and improve with corrective measures. We hypothesized that there are effects of land uses on soil organic carbon stock in relation to soil properties. With this back ground, an investigation was carried out to assess the soil organic carbon stock in the prevailing land uses under hot sub-humid dry agro ecological region of old alluvium Indo-Gangatic plains in South Bihar, India.

\section{Materials and Methods}

\section{Site selection}

Soil potential to stock organic carbon was planned in hot sub-humid dry agro ecological region (AER 13) of Indo-Gangetic plains, Eastern India with alluvium derived soils i.e old alluvium with growing period of 150-180 days. Agro Ecological Region (AER) Map published by National Bureau of Soil Survey and Land Use Planning, Nagpur was used to identify the AER in Bihar. Major part of the Bihar comes under Agro Ecological Region (AER) 13 followed by region 9. Out of total geographical area of 94163 sq. Km, 31.6 per area is under AER 9 (Fig. 1). In south Bihar, AER 9 occupies 29125 sq. $\mathrm{km}$ which is highest among other AERs. Mean annual rainfall is ranging from 700 to $1000 \mathrm{~mm}$ and potential evapo-transpiration ranging from 1300 to 1500 with mean temperature from 24 to $26{ }^{\circ} \mathrm{C}$.

"Soils of Bihar-their properties and classification" published by Rajendra Agricultural University, Bihar in 1986 was used to identify the alluvium under AER 9 in 
south Bihar (Fig. 2). Old alluvium of Ustifluent had spread in 8 districts in south Bihar. The study region is located in South Bihar and it was surveyed for prevailing land uses. There were six land uses viz., ricewheat-fallow system, maize-potato-fallow system, red gram, sugarcane, mango orchard and agro-forestry found prominent in the region. Five representative sites in each land use were selected for sampling in Jehanabad and Gaya district in south Bihar. Soil samples were collected from surface to $60 \mathrm{~cm}$ depth with $15 \mathrm{~cm}$ increments for soil organic carbon and core samples for bulk density estimation with standard procedures. Soil organic carbon stock was calculated up to $60 \mathrm{~cm}$ depth using soil organic carbon percentage and bulk density values.

\section{Land uses}

\section{Rice-wheat-fallow system}

Rice-Wheat-Fallow is traditional system in the low lands with limited use of organics and burnt crop residues left in the field after harvest. Among chemical fertilizers, urea as nitrogenous fertiliser, DAP / SSP as phophatic fertilizer and rarely potassic fertiliser are applied. The commonly grown rice varieties viz., MTU 7029, Gautam, Mansuri, Satyam, Kishori, Raj Shree, Pankaj, Swarnadhan Whereas wheat varieties include HUW 234, PBW 154, HD 2733 and HD 2824.

The recommended dose of NPK of is 100:60:50 kg per hectare but the farmers apply only $\mathrm{N}$ and $\mathrm{P}$ as Urea and DAP/SSP, respectively. At the time of sowing / transplanting (both rice and wheat) farmers apply DAP and thereafter Urea in two equal splits (tillering and panicle initiation). Generally, rice is grown during kharif as rainfed with limited irrigation with canal water and wheat during rabi with 2-3 irrigations.

\section{Maize-potato-fallow system}

Maize- potato is followed in the areas which are mid- lands and assured irrigation facilities are not available or light textured soils. After harvesting of kharif maize, potato crop is being grown and due to lack of moisture, land is kept vacantafter harvest of potato till sowing of kharif crop. Farmers are using urea, DAP and MOP in potato crops but only DAP and urea is used for maize crop. The commonly grown maize varieties are hybrids viz. PEHM-5, HQPM-1, HQPM-5, HQPM-7, Shaktiman-1 and 2, Ganga-11, DHM-117 etc. Potato varieties grown are K. Lalima, K. Sinduri, K. Pukhraj, K. Chipsona 1 and 2, K. Ashoka, K. Jyoti, K. Arun, Rajendra potato 1, 2 and 3 etc. The recommended dose of NPK in maize crop is 100: 60: $150 \mathrm{~kg} / \mathrm{ha}$ in three splits ( $\mathrm{N}$ and $\mathrm{K})$ while for potato recommended dose is 150: 90: 100. Recommended dose of FYM, $20 \mathrm{t} / \mathrm{ha}$ " is applied for potato crop at the time of field preparation. Kharif maize is generally grown as rainfed but if rainfall is not enough farmers give 1-2 irrigations to maize crop and for potato, 2-3 irrigations. Some farmers are practicing Potato + Maize (green cob) during rabi some sources of irrigation.

\section{Red gram cultivation}

Red gram is cultivated in the soils which are not suitable for rice cultivation or there are no irrigation facilities. It is also grown in uplands and alkali soils as rainfed crop. Generally, farmers are growing long duration varieties like Bahar, Pusa-9, Narendra Arhar-1 and 2, Mal 13, Pusa-9, Sharad, Prakash but few farmers are growing short duration varieties like ICPH-2671 and ICPL-2740 too.

The recommended dose of NPK are 20: 50:

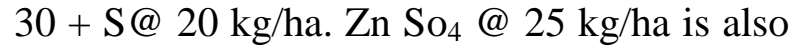
recommended before sowing but farmers are using only DAP and, in some cases, they are using DAP + MoP. Very few farmers (2-3) 
are using $\mathrm{S}$. The crop is growing as rainfed in upland and on field bunds.

\section{Sugarcane cultivation}

Sugarcane is grown in rice fields as well as in upland but area of sugarcane is declining at a faster rate due to long duration crop and high irrigation requirements to the crop. Varieties like BO-91, BO-110, BO- 147 and Co. L. 94184 are grown in rice fields whereas, varieties viz. BO- 91, BO-110, BO -136, KOPU. 2061, CO. PU. 9301 and 9702 are grown in uplands. Recommended dose of NPK are 125: $90: 60 \mathrm{~kg} / \mathrm{ha}$. FYM/compost is applied at the rate $20 \mathrm{t} / \mathrm{ha}$ before sowing but farmers are seldom applying FYM to this crop. Urea fertilizer is being applied in two splits: at the time of sowing and at the time of earthing up. Mostly farmers are growing spring planted sugarcane and applying 4-5 irrigations to the crop.

\section{Agroforestry (Dalbergia sissoo)}

The age of trees were varying from 10 to 20 years which are mainly planted in the boundaries of agricultural fields. Some places it is seen as bulk plantations inside agricultural fields up to 1 to 2 acres of land area. In recent years population of this tree is declining at a faster rate due to attack of insect or disease.

\section{Mango orchard}

Mango cultivation is dominant and there are many large mango orchards in the area. Mago is grown as sole crop in the area. The varieties grown in the area are of alternate bearing in nature. The dominant varieties are Langra (maldah), Mithua, Sindoori, Gulabkhas, Bombaiya, Sukul, Chausa, Sipia etc.

The recommended dose of NPK are 1.2: 0.3: $0.7 \mathrm{~kg} /$ adult tree. $75 \%$ of NPK are applied in the month of July i.e. after harvesting of the fruits and $25 \%$ in the month of April when small tender mangoes are seen on the trees. $50-60 \mathrm{~kg}$ of FYM or compost per tree are applied in a year. 150-200 trees/ha has been recorded during the survey. For newly planted orchards irrigation is being provided at 15 days interval while for old established orchards irrigation is being provided as and when it is necessary. Farmers are carrying out all the plant protection measures.

\section{Soil sampling and analysis}

Sampling sites were selected based on the long period cultivation of same crops. Cultivation history was collected from the farmers. Five sites were selected for profile sampling in each land use. Soil samples were collected at four depths viz., 0-15, 15-30, 3045 and $45-60 \mathrm{~cm}$. Soil core samples were collected for bulk density in all four depths. Soil sample collected from the core was dried at $105^{\circ} \mathrm{C}$ for $24 \mathrm{hrs}$ and weight was recoded. Core ring volume was calculated. Bulk density was calculated from weight by volume of the soil. Rock fragments of $>2 \mathrm{~mm}$ size was found in some soils. These portions were removed from the soil and the weight was taken. Volume of this portion was calculated by measuring of displaced water volume in the measuring cylinder.

Organic carbon was estimated with Walky and Black method as described by Jackson (1973). Analysis of soil microaggregates by Sarma and Das (1996), electrical conductivity, available potassium and zinc by (Jackson, 1973), available nitrogen by (Subbiah and Asija, 1956) and dehydrogenase activity by Casida et al., (1964).

\section{Estimation of soil organic carbon stock}

Soil organic carbon stock (SOCS), $\mathrm{kg} \mathrm{m}^{-2}$, was estimated from per cent organic carbon, bulk density and depth of soil with the following formula (Grossman et al., 2001). 


$$
\text { SOCS }=\frac{\mathrm{L}_{1} \times \mathrm{SOC} \mathrm{P}_{1} \times \rho 33_{1} \times\left(1-\mathrm{V}>2_{1}\right) / 100+\mathrm{L}_{2} \times \mathrm{SOCP}_{2} \times \rho 33_{2}\left(1-\mathrm{V}>2_{2}\right) / 100+\ldots}{10}
$$

Where,

SOC $=$ Soil organic carbon in $\mathrm{kg} \mathrm{m}^{-2}$ soil

SOC $\mathrm{P}_{1}, \mathrm{SOC}_{2}=$ Soil organic carbon per cent of different horizons $1,2, \ldots \mathrm{n}$ in order from surface to bottom

$\mathrm{L}_{1}, \mathrm{~L}_{2}, \ldots=$ Thickness of different horizons $1,2, \ldots \mathrm{n}$ in order from surface to bottom.

$\rho 33_{1}, \rho 33_{2}, \ldots=$ Bulk density of $<2 \mathrm{~mm}$ fraction of the core samples of horizons 1 , $2, . . \mathrm{n}$

$\mathrm{V}>2_{1}, \mathrm{~V}>2_{2}, \ldots=$ Volume per cent of $>2 \mathrm{~mm}$ fraction of core samples of horizons $1,2, . . n$

Where,

" $\rho$ " is the corrected bulk density $\left(\mathrm{Mg} \mathrm{m}^{-3}\right)$ by removing coarse fractions $>2 \mathrm{~mm}$ size including plant debris. The corrected bulk density is estimated with the following method.

$$
\rho=\frac{\text { Mass }_{\text {sample }}-\text { Mass }_{\text {rock fragments }}}{\text { Volume }_{\text {sample }}-} \frac{\text { Mass rock fragments }}{\rho_{\text {rock fragments }}}
$$

\section{Statistical analysis}

Descriptive statistics on soil organic carbon and bulk density and correlation analysis between soil organic carbon stocks and soil quality indicators were carried out using with Excel stat.

\section{Results and Discussion}

\section{Distribution of soil bulk density}

Soil compaction was found severe in RiceWheat system and recorded the highest BD $\left(1.58 \mathrm{Mg} \mathrm{M}^{-3}\right)$ with the range of 1.50 to 1.62 $\mathrm{Mg} \mathrm{M}^{-3}$ (Table 1). High standard deviation was also found with this land use within the profile. High bulk density was observed in the middle layers compared to surface and lowest layer of the profile which might be due to higher compaction occurred because of wet tillage followed for rice crop. Translocation of clay at the time of wet tillage and settling in the subsurface layers was the reason for higher bulk density in dry condition. Second highest bulk density was recorded with red gram $\left(1.54 \mathrm{Mg} \mathrm{M}^{-3}\right)$ ranging from 1.52 to 1.59 $\mathrm{Mg} \mathrm{M}^{-3}$. In the profile, the highest density was observed at surface layer and it was decreasing linearly from surface layer to lowest layer. Variation in bulk density among the soil layer was less compared to RiceWheat system. The third highest bulk density was recorded in agroforestry soils $(1.49 \mathrm{Mg}$ $\mathrm{M}^{-3}$ ) ranged from 1.47 to $1.50 \mathrm{Mg} \mathrm{M}^{-3}$. The density was higher at middle layer of profile under agro-forestry (with Dalbergia sissoo Sheesham trees) because they are grown as hedge trees in rice wheat system. However the bulk density under agro-forestry was lesser than rice -wheat system. The litter fall and addition of organics under agro-forestry might have reduced the bulk density. Fourth higher density was recorded in mango orchard where the density was lower in the surface and found higher density in subsurface. Higher variance was observed in the profile which may be due to higher litter 
accumulation in the surface layer with lower bulk density and more compaction in lower layers. Maize-Potato system maintained fifth higher bulk density of $1.44 \mathrm{Mg} \mathrm{M}^{-3}$ with lower level of variance among bulk density in the profile. Surgarcane growing soil maintained the lowest bulk density among six land uses with less variance in the profile ranging from 1.39 to $1.36 \mathrm{Mg} \mathrm{M}^{-3}$. Intensive cultivation with heavy tillage might have loosened the soil and maintained low density.

\section{Distribution of soil organic carbon}

Soil organic carbon was varying in various layers upto $60 \mathrm{~cm}$ of depth and in six land uses from 0.22 to 1.32 per cent in the Old alluvium of Indo - Gangetic plains under hot -sub-humid dry agro eco region (Table 2). The highest soil organic carbon was recorded in mango orchard with very high variance among the profile carbon. Tree had been found to accumulate more organic carbon in soil (Tomlinson et al., 1995). The mean organic carbon in mango orchard of 0.84 per cent is 2.23 time higher than sugarcane growing soils in the same agro-eco system. Perennial vegetation of mango orchard has accumulated higher quantity of organic matter in soil might have added higher quantity of organic carbon. The variance in carbon content was highest in the profile of mango orchard it might be due accumulation of litters in the surface layer and lower carbon content in subsurface layers. Maize-Potato system recorded higher organic carbon next to mango orchard of 0.60 per cent which was 1.58 times higher than sugarcane growing soils with moderate variance among profile carbon. Third highest soil organic carbon was recorded with agro-forestry system with 0.59 per cent and which was 1.55 times higher than sugarcane growing soils with the variance of 0.061 . It might be due to addition of organic matter through litter fall from the tree (Dalbergia sissoo). Rice-wheat system recorded the carbon content of 0.47 per cent which was 1.24 times higher with lower variance in profile carbon. It has maintained better carbon content than red gram and sugarcane growing soils might be with the addition of manures and with its own residues. Red gram growing which soils have maintained only lower level of organic carbon and it was next higher to the lowest of sugarcane growing soil. Red gram is grown in uplands in rain-fed condition as single crop in a year; hence, the organic addition is poor in the soil. The lowest soil organic carbon was recorded in sugarcane growing soils with lower variance in the profile. Sugarcane being grown continuously with intensive cultivation with heavy tillage. Sugarcane is an exhaustive crop and heavy feeder of nutrients.

Soil organic carbon stock and its relationship with soil properties

The soil organic carbon stock was observed highest in mango orchards with $9.6 \mathrm{~kg} \mathrm{~m}^{-2}$ (Table 3). The age of mango orchards in the region are varying from 50 to 70 years of age. The land areas under the trees are not used for cultivation and there is no-tillage activities which might have stored higher quantity of carbon in the soil. Continuous litter fall for long time could be the possible reason for accumulation of higher organic carbon stock in mango orchard in Alfisol (Roy, 2016). Agroforestry system of Dalbergia sissoo recorded the soil organic stock of $7.9 \mathrm{~kg} \mathrm{~m}^{-2}$. Higher leaf litter fall at surface of tree based cropping system which increases carbon input into the soil and in turn act as mulch, cooling the soil surface and reduces the soil OM oxidation (Grigal and Berguson, 1998). Soils under intensively cultivable land of Maizepotato cropping system recorded the soil organic carbon stock of $6.7 \mathrm{~kg} \mathrm{~m} \mathrm{~m}^{-2}$. Continuous cultivation of cereals in potato based cropping system increases the light fraction carbon which ultimately increased the carbon content in soil (Angers et al., 1999). Above ground biomass of potato was allowed 
to decay in the field itself before harvesting of tubers and maize crop adds lot of biomass in the form of root. Rice-Wheat cropping system recorded the soil organic carbon stock of 6.4 $\mathrm{kg} \mathrm{m}{ }^{-2}$ which is higher than red gram and sugarcane growing soils in the region, hence, Rice-Wheat system have reasonably maintained the organic carbon stock in old alluvium. Red gram mono-crop recorded 5.8 $\mathrm{kg} \mathrm{m}^{-2}$ of soil organic carbon stock. Single crop is grown in uplands with poor irrigation facilities. Hence, the carbon accumulation is poor. The lowest organic carbon stock of 4.2 $\mathrm{kg} \mathrm{m}^{-2}$ was recorded in sugarcane growing soils. Farmers apply less amount of manures and fertilizer to sugarcane crop which might be the reason for poor organic carbon stock.

Organic carbon stocks supports soil physical, chemical and biological quality which supports the soil productivity. Soils under old alluvium also found that soil organic carbon stocks positively and significantly influenced the soil properties such as soil microaggregates (Poch and Antunez 2010), electrical conductivity, available nitrogen, potassium, available zinc and dehydrogenase activities (Fig. 3). It shows that when the soil organic carbon stock increases the soil qualities also increase. Under different land use system and management practices the amount of light fraction would increase that enhances the rate of nutrient cycling through microbial biomass and may increase the overall availability of nutrients in soil (Dalal and Mayer, 1987) Available soil nutrients observed to decrease in cultivable soil compared to uncultivable and natural forest soils (Kaushik et al., 2018).

Table.1 Soil bulk density in the profiles of different land uses $\left(\mathrm{Mg} \mathrm{m}^{-3}\right)$

\begin{tabular}{|l|c|c|c|c|c|c|}
\hline $\begin{array}{c}\text { Depth } \\
\text { (cm) }\end{array}$ & $\begin{array}{c}\text { Rice-Wheat- } \\
\text { Fallow }\end{array}$ & $\begin{array}{c}\text { Maize-Potato- } \\
\text { Fallow }\end{array}$ & Red gram & Sugarcane & $\begin{array}{c}\text { Mango } \\
\text { Orchard }\end{array}$ & $\begin{array}{c}\text { Agro- } \\
\text { forestry }\end{array}$ \\
\hline $\mathbf{0 - 1 5}$ & 1.50 & 1.40 & 1.59 & 1.39 & 1.38 & 1.49 \\
\hline $\mathbf{1 5 - 3 0}$ & 1.62 & 1.43 & 1.54 & 1.41 & 1.49 & 1.47 \\
\hline $\mathbf{3 0 - 4 5}$ & 1.61 & 1.47 & 1.52 & 1.45 & 1.48 & 1.50 \\
\hline $\mathbf{4 5 - 6 0}$ & 1.60 & 1.44 & 1.55 & 1.46 & 1.48 & 1.50 \\
\hline Mean & 1.583 & 1.435 & 1.550 & 1.428 & 1.458 & 1.490 \\
\hline $\begin{array}{l}\text { Std. } \\
\text { Deviation }\end{array}$ & 0.056 & 0.029 & 0.029 & 0.033 & 0.052 & 0.014 \\
\hline Variance & 0.003 & 0.001 & 0.001 & 0.001 & 0.003 & 0.000 \\
\hline
\end{tabular}

Table.2 Soil organic carbon in the profiles of different land uses (\%)

\begin{tabular}{|l|c|c|c|c|c|c|}
\hline $\begin{array}{c}\text { Depth } \\
\text { (cm) }\end{array}$ & $\begin{array}{c}\text { Rice-Wheat- } \\
\text { Fallow }\end{array}$ & $\begin{array}{c}\text { Maize-Potato- } \\
\text { Fallow }\end{array}$ & $\begin{array}{c}\text { Red } \\
\text { gram }\end{array}$ & Sugarcane & $\begin{array}{c}\text { Mango } \\
\text { Orchard }\end{array}$ & $\begin{array}{c}\text { Agro- } \\
\text { forestry }\end{array}$ \\
\hline $\mathbf{0 - 1 5}$ & 0.55 & 0.78 & 0.71 & 0.49 & 1.32 & 0.89 \\
\hline $\mathbf{1 5 - 3 0}$ & 0.58 & 0.66 & 0.49 & 0.34 & 0.65 & 0.69 \\
\hline $\mathbf{3 0 - 4 5}$ & 0.41 & 0.53 & 0.32 & 0.45 & 0.68 & 0.35 \\
\hline $\mathbf{4 5 - 6 0}$ & 0.34 & 0.41 & 0.22 & 0.22 & 0.69 & 0.43 \\
\hline Mean & 0.470 & 0.595 & 0.435 & 0.375 & 0.835 & 0.590 \\
\hline $\begin{array}{l}\text { Std. } \\
\text { Deviation }\end{array}$ & 0.114 & 0.160 & 0.215 & 0.121 & 0.324 & 0.247 \\
\hline Variance & 0.013 & 0.026 & 0.046 & 0.015 & 0.105 & 0.061 \\
\hline
\end{tabular}


Table.3 Soil organic carbon stock in the profiles of different land uses $\left(\mathrm{kg} \mathrm{m}^{-3}\right)$

\begin{tabular}{|c|c|c|c|c|c|c|}
\hline $\begin{array}{c}\text { Depth } \\
\text { (cm) }\end{array}$ & $\begin{array}{c}\text { Rice- } \\
\text { Wheat- } \\
\text { Fallow }\end{array}$ & $\begin{array}{c}\text { Maize- } \\
\text { Potato- } \\
\text { Fallow }\end{array}$ & Red gram & Sugarcane & $\begin{array}{c}\text { Mango } \\
\text { Orchard }\end{array}$ & $\begin{array}{c}\text { Agro- } \\
\text { forestry }\end{array}$ \\
\hline $\mathbf{0 - 1 5}$ & 2.07 & 2.09 & 2.45 & 1.30 & 3.44 & 2.70 \\
\hline $\mathbf{1 5 - 3 0}$ & 1.69 & 1.85 & 1.59 & 0.93 & 1.97 & 2.04 \\
\hline $\mathbf{3 0 - 4 5}$ & 1.45 & 1.57 & 1.01 & 1.29 & 2.04 & 1.08 \\
\hline $\mathbf{4 5 - 6 0}$ & 1.19 & 1.16 & 0.72 & 0.64 & 2.07 & 1.32 \\
\hline
\end{tabular}

Fig.1 Agro ecological regions of Bihar

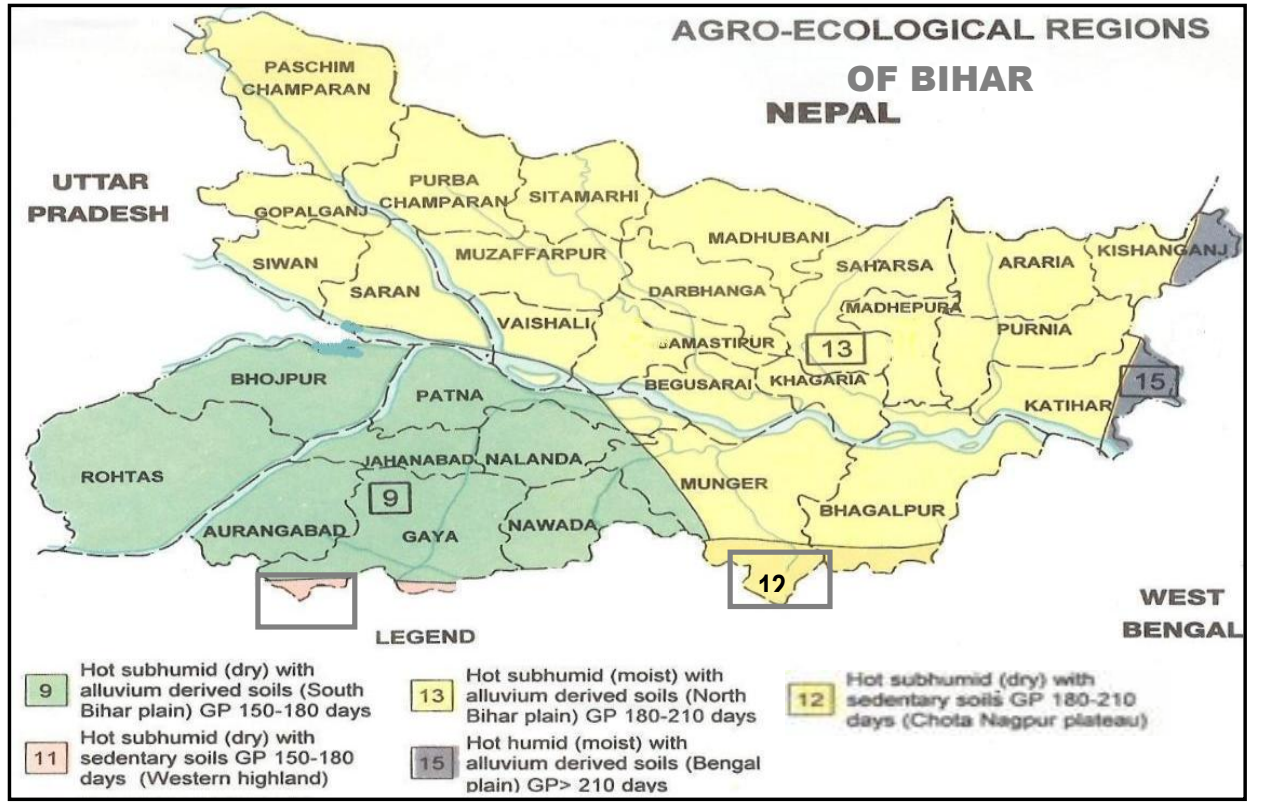

Fig.2 Area under old alluvium in Agro Ecological Region 9.0 in south Bihar

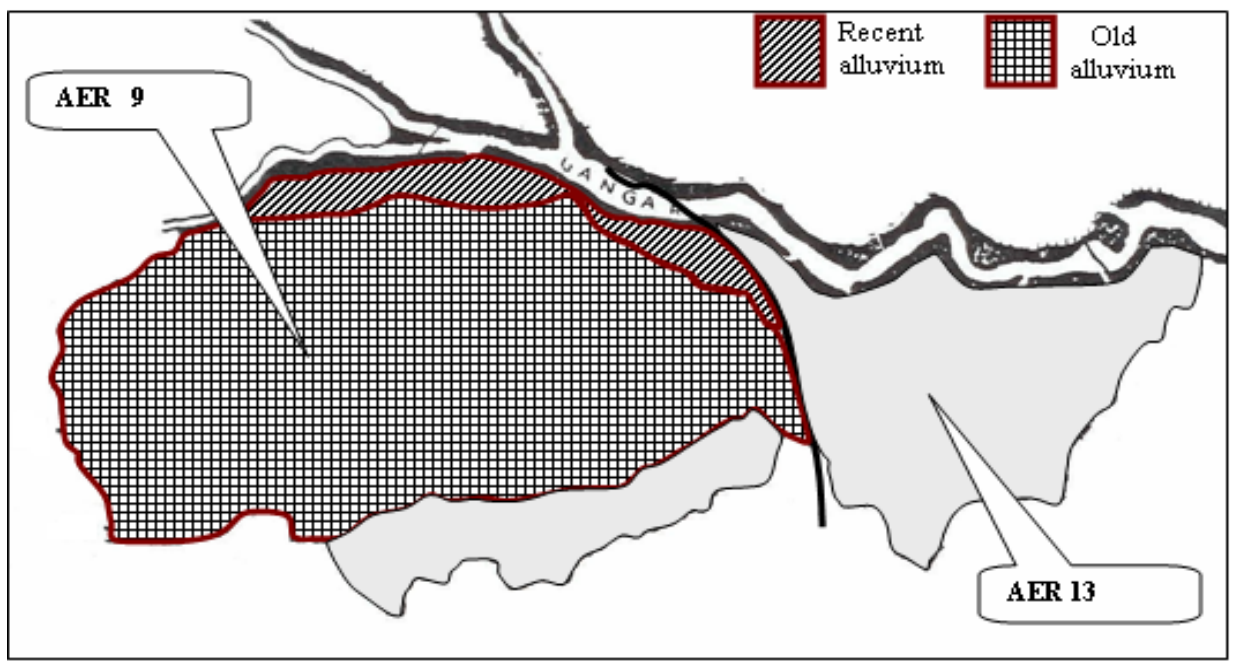


Fig.3 Association of soil organic carbon stock with soil micro aggregates (a), electrical conductivity (b), available nitrogen (c), available potassium (d), available zinc (e) and dehydrogenase activity (f) in old alluvium of Agro Ecological Region - 9.0

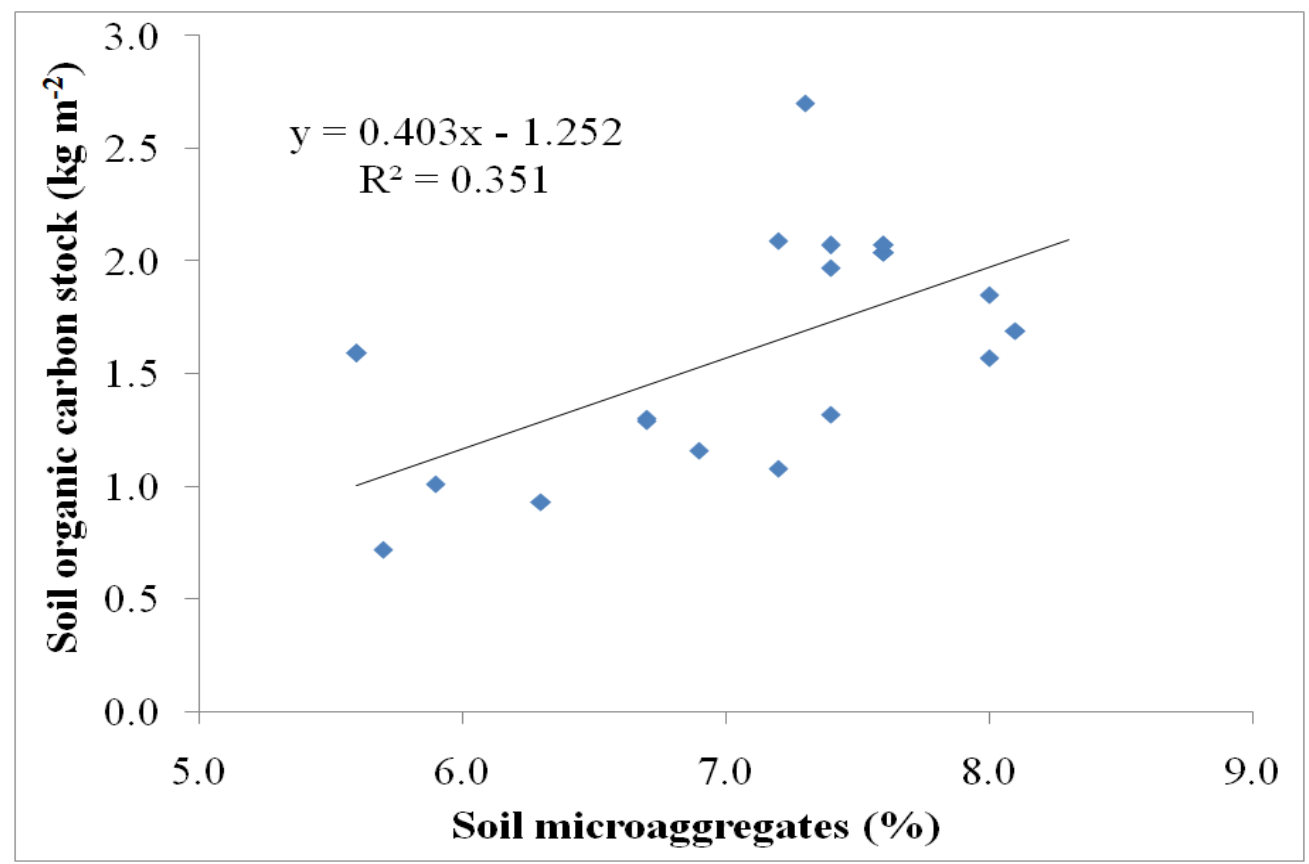

(a)

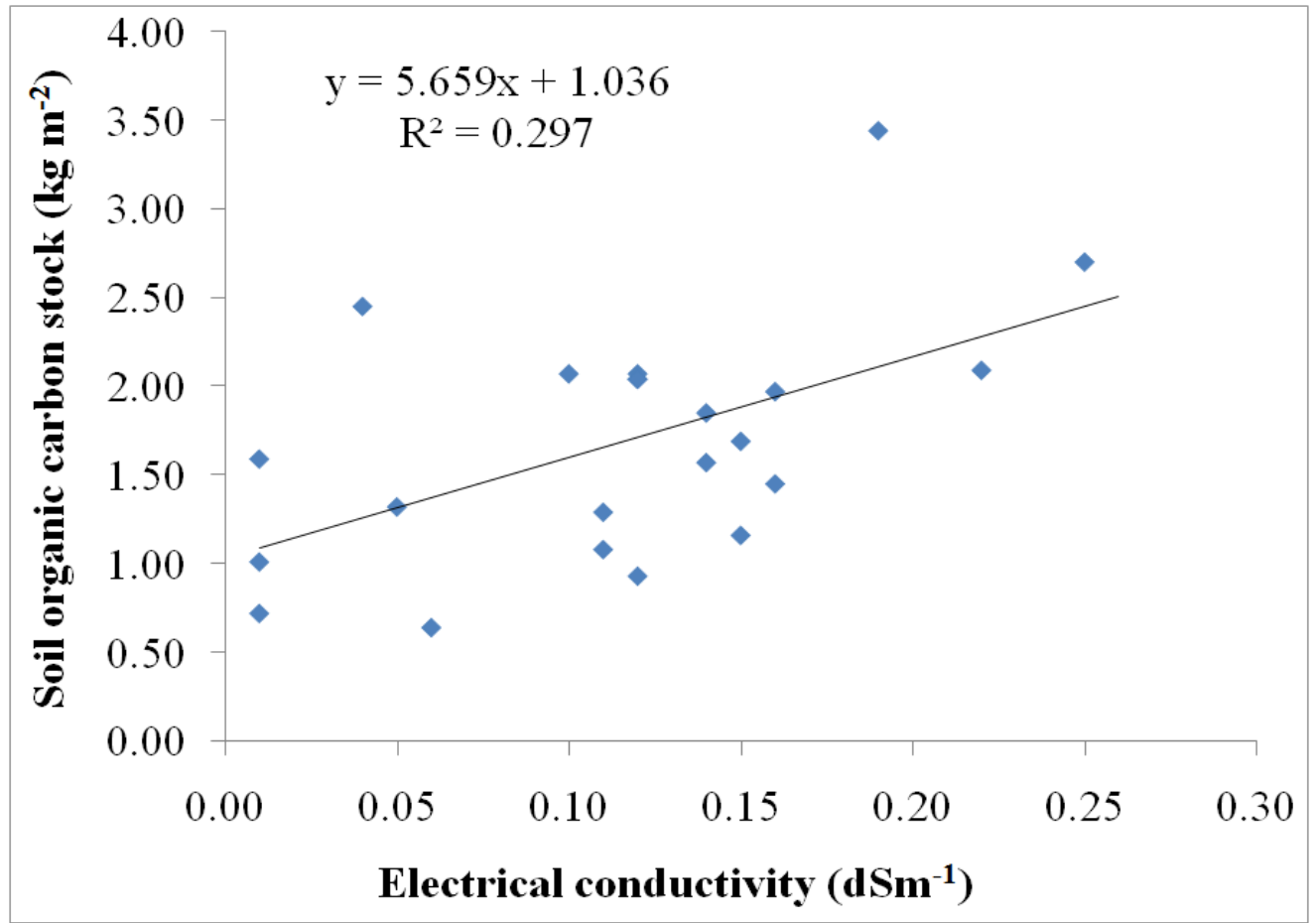

(b) 


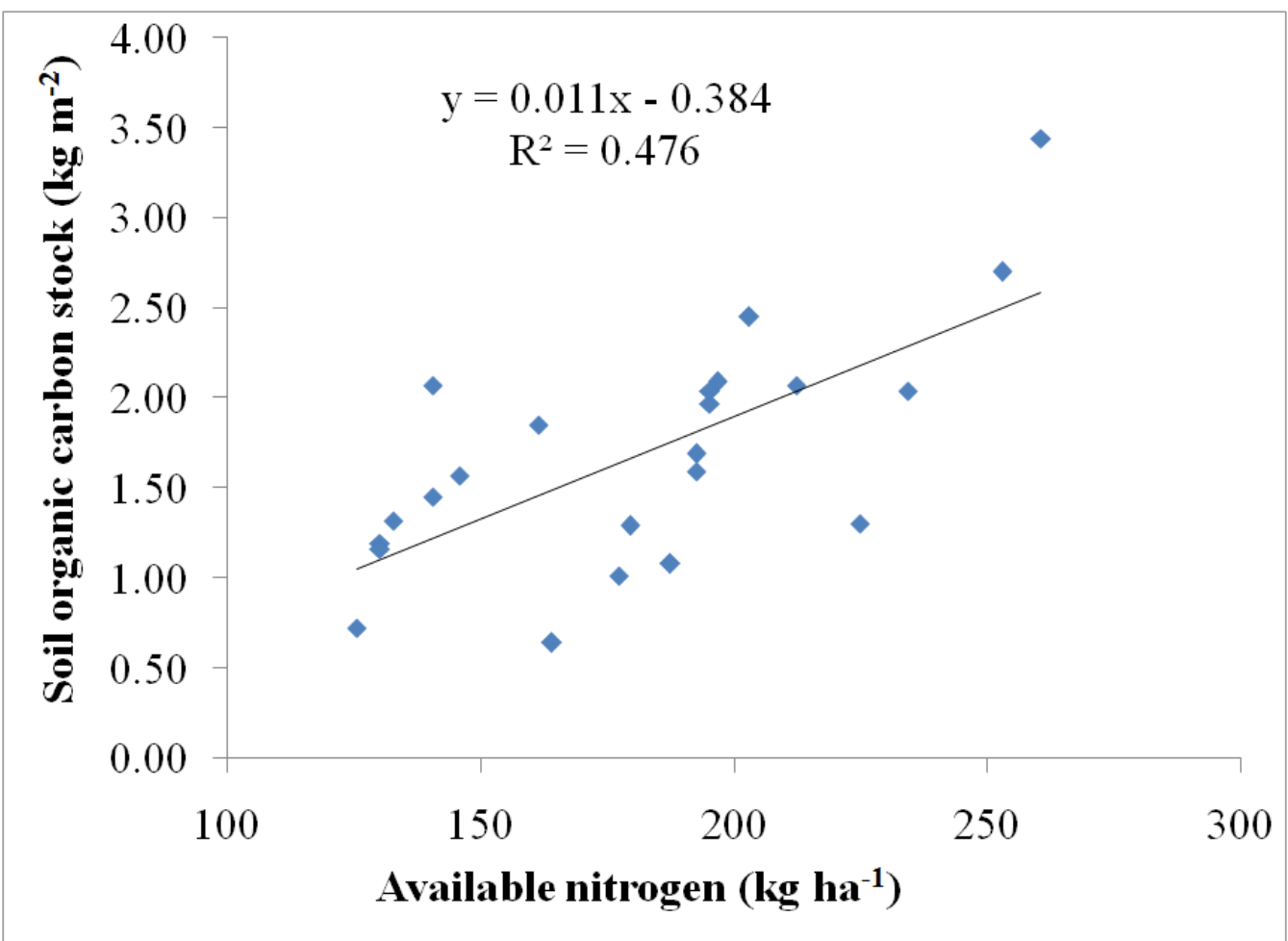

(c)

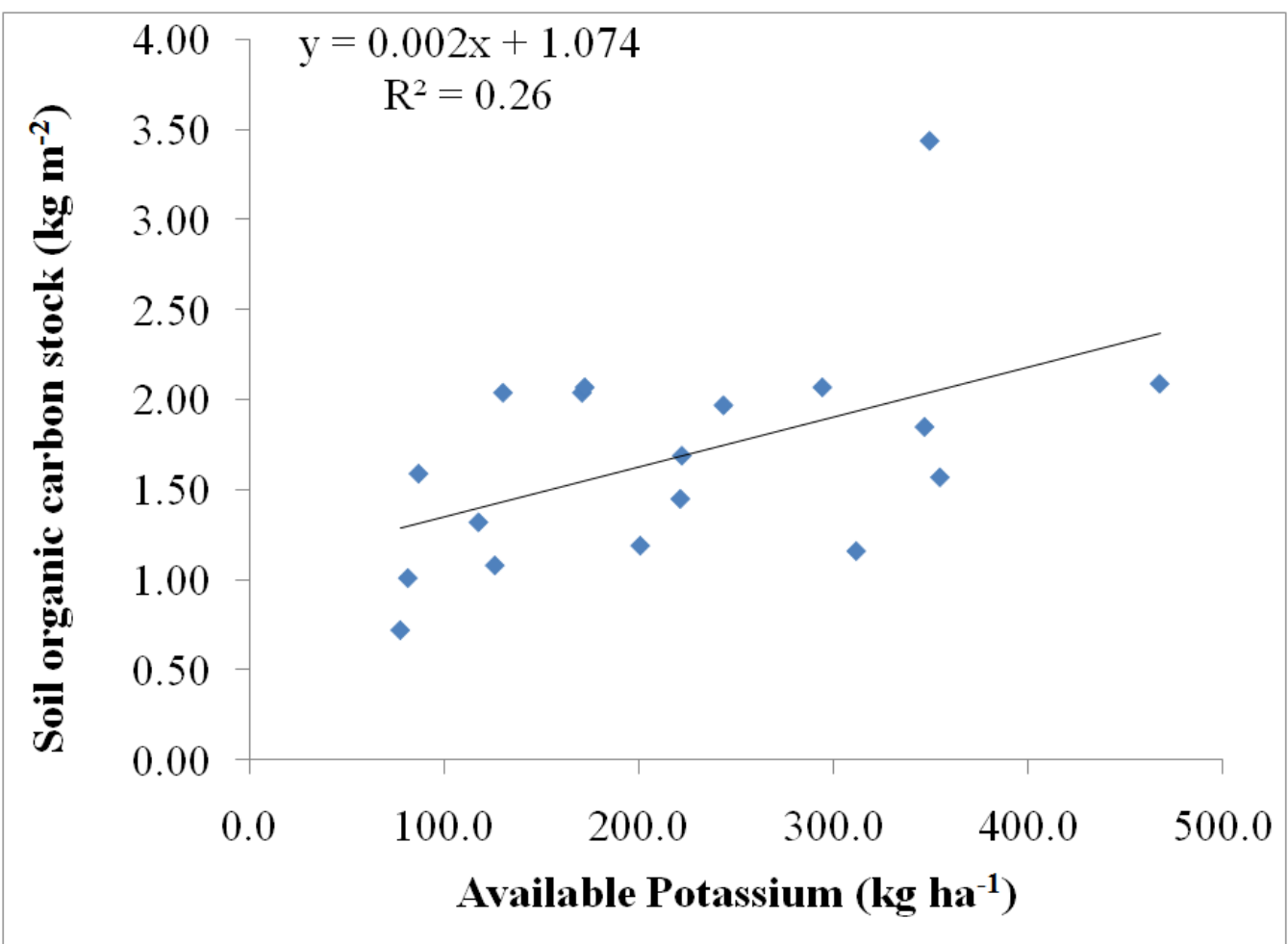

(d) 


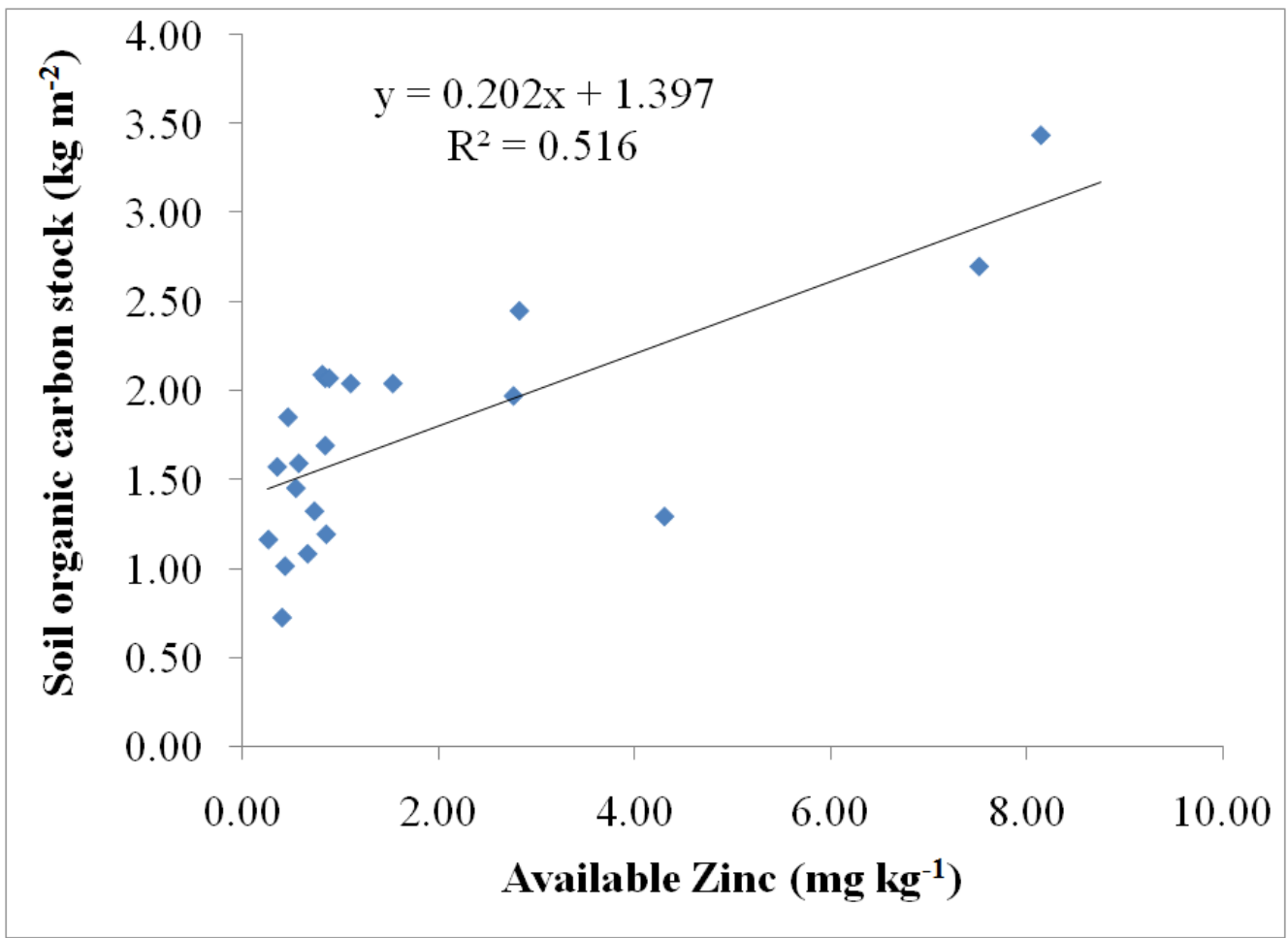

(e)

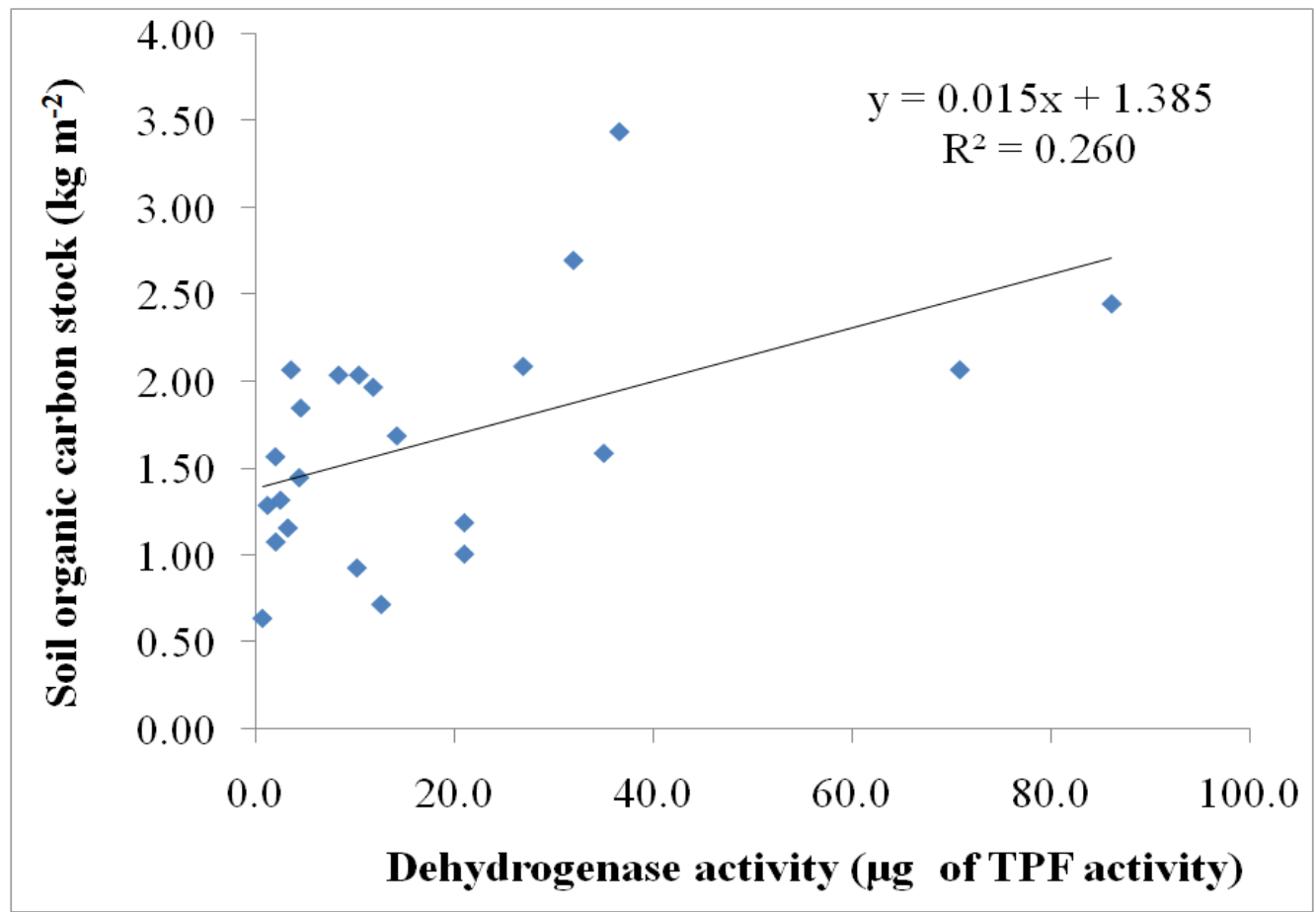

(f)

\section{Carbon sequestration potential}

Mango orchard observed as a stabilized agroeco system and maintained highest soil organic carbon stock in the region. It has stored 96 tonnes of organic carbon per hectare area as observed by Roy (2016). The lowest soil organic carbon stock was recorded under 
sugarcane growing soils which has recorded only 44 per cent of Mango orchard. Sugarcane growing soil has a potential for storing $54 \mathrm{t} \mathrm{ha}^{-1}$ of organic carbon in the agro eco region. Regular addition of higher quantity of manures, inclusion of green manures in between two crops, adding green leaf manure and growing green manure crops such as green gram, black gram, soybean in the initial period of sugarcane will enhance the carbon status in the soil. Red gram soil has stored $58 \mathrm{t} \mathrm{ha}^{-1}$ of organic carbon which consists of 60 per cent of SOCS found in Mango orchard. The Red gram growing soil still has the potential of storing $38 \mathrm{t} \mathrm{ha}^{-1}$ of organic carbon in the region. When the red gram is grown in upland condition with irrigation and good management, biomass production and soil carbon status will improve compared to poor management and rainfed conditions. Rice-Wheat-Fallow system stored $64 \mathrm{t} \mathrm{ha}^{-1}$ of organic carbon which is 67 per cent that of Mango orchard soils and it has a potential of storing $32 \mathrm{t} \mathrm{ha}^{-1}$ of organic carbon in Rice-Wheat-Fallow system in the agro eco system. Intensive cultivation with rice and wheat tend to reduce the carbon stock in the soil due to exposure of carbon for fast decomposition. Incorporation of manures, balanced use of fertilizers and minimum tillage practices in rice-wheatfallow system will increase organic carbon stock in the soil. Maize-Potato-Fallow system in the region has stored $67 \mathrm{t} \mathrm{ha}^{-1}$ of organic carbon and still it has a potential of storing 29 tonnes of organic carbon per hectare. Maize is grown rainfed and its biomass production above and below ground level is high compare to rice biomass during khairf and the biomass of potato is fully incorporated in the field itself. Hence the SOCS is better compared to rice-wheat-fallow system in the eco region.

Agroforestry with Dalbergia sissoo recorded the SOCS of $79 \mathrm{t} \mathrm{ha}^{-1}$ which consist of 82 per cent as found in soils of Mango orchards. However, agro forestry till has the potential to store $23 \mathrm{t} \mathrm{ha}^{-1}$ of organic carbon. Planting of Dalbergia sisso with higher density with pest and disease control will improve higher biomass production and soil carbon. Growing of multipurpose trees along with agricultural crops, is a potent option to sequester the above- and below-ground carbon into the soils (Gupta et al., 2009).

In conclusion, soil organic carbon stocks was assessed in six land uses under old alluvium of agro ecological region 9 of South Bihar under Indo-Gangetic plains, India. In an identical climatic condition and soil, management aspects are developing varied level of soil quality and carbon stocks. The land uses varied from intensively cultivated system to limited disturbed system. Among six land uses, Mango orchard stored highest organic carbon stock in AER 9.0 which can be taken as bench mark and SOCS of other land uses can be increased. Potential for sequestering soil organic carbon was varying from 23 to $54 \mathrm{t} \mathrm{ha}^{-1}$ in other land uses compared to most stabilized land uses of Mango orchard. Perennial vegetations have proved to accumulate high organic carbon in the soil. Introduction of agro-forestry or tree based cultivation may improve the carbon stocks in the old alluvium of Indo-Gangetic plains.

\section{References}

Angers, Denis A., Linnell M. Edwards, J.Brian Sanderson, and Nicole Bissonnette (1999) Soil organic matter quality and aggregate stability under eight potato cropping sequences in a fine sandy loam of Prince Edward Island. Canadian Journal of Soil Science, 79(3), 411-417.

Awasthi, K. D., Singh, B. R., and Sitaula, B. K (2005) Profile carbon and nutrient 
levels and management effect on soil quality indicators in the Mardi watershed of Nepal. Acta Agriculture Scandinavica section $b$-soil and plant, 55,192-204.

Casida, J. E., Klein, D. A. and Santoro, T. (1964) Soil dehydrogenase activity. Soil Science, 98, 371-376.

Dalal, R.C. and Mayer, R.J. (1987) Long term trends in fertility of soils under continuous cultivation and cereal cropping in southern Queensland VII. Dynamics of nitrogen mineralization potentials and microbial biomass. Australian Journal of Soil Research, 25, 461-472.

Grigal, D. F. and Berguson, W.E. (1998) Soil carbon changes associated with shortrotation systems. Biomass Bioenergy, 14, 371-377.

Grossman, R. B., Harrms, D. S., Kinngsbury, D. F., Shaw, R. K. and Jenkins, A. B. (2001) Assessment of soil organic carbon using the U.S Soil Survey. In: Assessment Methods for Soil Carbon (Eds. R. Lal, J. Kimble, R.F. Follet and Stewart, B. A.), CRC Press. Boca Raton, pp. 87-102.

Gupta, N., Kukal, S.S., Bawa, S.S., Dhaliwa, G.S.(2009) Soil organic carbon and aggregation under poplar based agroforestry system in relation to tree age and soil type. Agroforestry System, $76,27-35$.

Guo, L. B., and Gifford, M. (2002) Soil carbon stocks and land use change: A meta analysis. Global change biology, $8,345-360$.

Jackson, M. L. (1973) Soil chemical analysis, Printice Hall, New Delhi.

Jungqvist, G., Oni, S.K., Teutschbein, C. and Futter, M.N. (2014) Effects of climate change on soil temperature in Swedish boreal forests. PLoS One, 9, e93957.

Kaushik, Usha, Raj Dev, Rani Pooja and Bhardwaj, K.K. (2018) Effect of
Cultivation on Organic Carbon Pools and Nutrient Availability in Soil under Different Land Use System: A Review. International Journal of Current Microbiology and Applied Science, 7(8), 1578-1591

Krishnan, P., Bourgeon, G., Lo Seen, D., Nair, K.M., Prasanna, R., Srinivas, S., Muthusankar, G., Dufy, L. and Ramesh, B. R. (2007) Organic carbon stock map for soils of south India: A multifactorial approach. Current Science, 93,706-710.

Lindroth, A., Grelle, A. and Móren, A.S. (1998) Long-term measurements of boreal forest carbon balance reveal large temperature sensitivity. Global Change Biology, 4, 443-450.

Lugo, E. A., Sanchez, J. M., and Brown, S. (1986) Land use and organic carbon content of some subtropical soils, Plant Soil, 96, 185- 196.

Marín-Spiotta, E. and Sharma, S. (2013) Carbon storage in successional and plantation forest soils: a tropical analysis. Global Ecology Biogeography, $22,105-117$.

Ollinger, S.V., Smith, M.L., Martin, M.E., Hallett, R.A., Goodale, C.L., Aber, J.D., 2002. Regional variation in foliar chemistry and $\mathrm{N}$ cycling among forests of diverse history and composition. Ecology, 83, 339-355.

Poch RM, AntUnez M (2010) Aggregate development and organic matter storage in Mediterranean mountain soils. Pedosphere, 20, 702-710

Rajan, K., Natarajan, A Anil Kumar K. S., Badrinath, M S., Gowda, R C. (2010) Soil organic carbon - a most reliable soil quality indicator for monitoring land degradation by soil erosion. Current Science, 99, 823-827.

Roy Poushali. (2016) C sequestration potential of cultivated land and Mango orchard in the plough layer of Alfisols of the tropical sub-humid dry 
bioclimatic zone of India. Tomlinson, H., Teklehaimanot Z., Traoré A., Agropedology, 26 (01), 10-21

Sarma, P.K. and Das, M. (1996) Effect of aggregating agents on synthesis of microaggregates and physical properties of an Alfisols. Journal of the Indian Society of Soil Science, 44, 12-15.

Sjögersten, S. and Wookey, P.A. (2009) The impact of climate change on ecosystem carbon dynamics at the Scandinavian mountain birch forest - Tundra Heath Ecotone Ambio, 38, 1-1.

Subbiah, B.V. and Asija, G.L. (1956) A rapid procedure for the determination of available nitrogen in soils. Current Science, 25, 259-260.

Olapade E. (1995) Soil amelioration and root symbioses of Parkia biglobosa (Jacq.) Benth. in West Africa. Agroforestry Systems, 30, 145-159.

Walkly, A. and Black, I.A. (1934) An estimation of the degtjareff method for determining soil organic matter and a proposed modification of the chromic acid titration method. Soil Science, 34, 29-38.

Wang, J., Fu, B., Qiu, Y., and Chen, L. (2003) Analysis on soil nutrient characteristics for sustainable land use in Danangou catchment of the Loess Plateau, China. Catena, 54, 17-29.

\section{How to cite this article:}

Rajan, K., Sanjeev Kumar, D. Dinesh, P. Raja, B.P. Bhatt and Deo Karan. 2019. Appraisal of Soil Potential to Store Organic Carbon in Old Alluvium of Indo-Genetic Plains. Int.J.Curr.Microbiol.App.Sci. 8(03): 2089-2102. doi: https://doi.org/10.20546/ijcmas.2019.803.249 